\title{
MARTALISHVILI L.
}

Poltava V. G. Korolenko national pedagogical University, Ukraine

\section{THE THEORETICAL FUNDAMENTALS OF UKRAINE EDUCATION PUBLIC ADMINISTRATION AND TRENDS OF ITS MODERN DEVELOPMENT}

Today the problem of public administration in Ukraine exists not only in education. But education is a basic industry that lays the foundations for the state economic development in the future. It is especially important to initiate education reform precisely because of changes in the governance system. The article describes the results of studies of the historical and structural aspects of the system of public administration, which have formed in Ukraine over the last 100 years. Now Ukrainian scientists are just beginning to explore this topic.

Scientists have fundamentally justified the classical approach to education public administration. Researchers in public administration viewed it as a process of planning, organizing, motivating and controlling. Classical public administration has shaped specific goals of the education sector. Then it worked on the problems of achieving the set goals. The modern world and society require changes in the relationship between the state and the education system. This is reflected in state educational doctrines, legislation, state educational standards.

The article reveals the need for changes in the context of the world tendencies of reforming the education sector, examples of changing approaches to public administration in the leading countries of the world are given.

Ukraine has a crisis in the educational sector. In recent decades, funding in education has decreased; Reduced teacher pay; poor logistical support for schools; bureaucratization of the education management system; outdated content of education and teaching methods. In 2017 began the process of modernization of the general secondary education system. The Reform NUS has touched many areas of education, including governance. Modern society requires that the education state administration to replace the control function with the regulatory one. The Intelligent governance should take the utmost account of the interests and needs of different social groups.

The author describes the first steps of the reform of the board of education in Ukraine and perspective trends. Education public administration in the modern world acquires characteristic signs of dependence on socio-political, economic processes, and therefore requires new approaches to the scientific research of its essence.

Keywords: Public Administration of Education. The influence of the state on education. Reform NUS.

Стаття надійшла до редакції 16.10.2019 р.

УдК 378.011.3-051:613/614

DOI: https://doi.org/10.33989/2075-146x.2019.24.194859

ОЛЕНА МОМОТ

ORCID ID 0000-0001-9187-1036

ГАННА КИРИЛЕНКО

ORCID ID 0000-0001-7635-8840

Полтавський національний педагогіний університет імені В. Г. Короленка

\section{ФОРМУВАННЯ КУЛЬТУРИ ЗДОРОВ'Я ОСОБИСТОСТІ МАЙБУТНЬОГО ВЧИТЕЛЯ В ЗДОРОВ'ЯЗБЕРЕЖУВАЛЬНОМУ СЕРЕДОВИЩІ ЗАКЛАДУ ВИЩОЇ ОСВІТИ}

\footnotetext{
Розкрито ідеї щодо формування культури здоров'я, попередження шкідливих звичок у студентів (тютюнопаління, алкоголізм, наркоманію) засобами методичних порад i рекомендацій в здоров'язбережувальному середовищі закладу вищої освіти, які виховують якість людини, що відображає характер зацікавленого особистого ставлення до здорового способу життя та навколишнього середовища.
}

Ключові слова: формування культури здоров'я; особистість майбутнього вчителя; здоров'язбережувальне середовище; здоров'я; заклад вищої освіти

Постановка проблеми. Майбутній фахівець - особистість освічена, духовно багата, фізично міцна, загартована. У системі вишівської підготовки необхідно особливу увагу приділити формуванню культури здоров'я в особистостей майбутніх учителів. Ця проблема актуальна ще й у зв'язку з тим, що, «вчителі не можуть успішно формувати особистість учня, долучати його до фізичної культури, якщо самі не займаються фізичним самовихованням, часто 
хворіють, не дотримуються здорового способу життя. Сучасна школа вимагає від вчителя знань, умінь і навичок у галузі фізичної культури і здоров'язбережування. Підростаюче покоління неможливо сформувати активним, якщо педагог буде залишатися пасивним» (Минияров, 1992, с. 116).

Аналіз останніх досліджень i публікацій засвідчує багатогранність проблеми здоров'язбережування: обгрунтовано принципи, зміст, форми й методи педагогіки здоров'я як галузі педагогічного знання (Ю. Бойчук, В. Горащук, М. Гриньова, В. Левченко, М. Лук'янченко, С. Омельченко, В. Оржеховська, М. Смірнов, В. Ткаченко, А. Цьось та ін.); аргументовано цілісний підхід до формування здоров’я людини (Г. Апанасенко, Т. Бойченко, М. Гончаренко та ін.); розроблено шляхи створення здоров'язбережувального освітнього середовища (О. Малихін, Ю. Мануйлов, Т. Миронюк, Н. Тарасенко та ін.); створено методологічні засади здоров'язбережувальної діяльності (Н. Башавець С. Закопайло, Н. Завидівська, В. Омельяненко, В. Оржеховська, С. Страшко та ін.); досліджено теоретичне підгрунтя для застосування здоров'язбережувальних технологій у навчальній та позанавчальній діяльності (О. Ващенко, Д. Воронін, С. Гаркуша, В. Єфімова, О. Міхеєнко, М. Носко, В. Петров та ін.).

Мета статті: формувати культуру здоров'я, попереджати шкідливі звички у студентів (тютюнопаління, алкоголізм, наркоманію) засобами методичних порад і рекомендацій в здоров'язбережувальному середовищаі закладу вищої освіти

Виклад основного матеріалу. Під культурою здоров'я розуміємо динамічний стереотип поведінки, що сприяє здоровому способу життя та визначає дбайливе ставлення до здоров'я оточення (Колбанов, Берсенева, 1995, с. 54). Це індивідуальна і соціальна якість людини, що відображає характер зацікавленого особистого ставлення до здорового способу життя та навколишнього середовища, що виявляється в процесі індивідуальної участі в духовно-практичній діяльності з пізнання, освоєння, перетворення і збереження свого здоров'я як особистого енергоресурсу успішної життєдіяльності (Митяева, 2008, с. 13). 3 цього визначення випливає, що культура здоров'я є важливою умовою збереження власного здоров'я особистості та інструментом у формуванні суспільного здоров'я.

Однак ставлення до власного здоров'я в значної частини майбутніх учителів залишається пасивним. У зв'язку з погіршенням стану здоров'я не тільки студентської молоді, а й населення в цілому, екологічними проблемами, стресовими кризовими станами в самому суспільстві й іншими несприятливими факторами назріла потреба змінити таке відношення до стану свого організму.

Сформувати культуру здоров'я в майбутніх учителів можна тоді, коли вони будуть зорієнтовані на здоров'язбережування самою системою педагогічної освіти. Педагогічний ефект повинен полягати не тільки в нагромадженні нових знань, умінь і навичок, розвитку позитивного мотиваційного ставлення до здоров'я, але й виражатися в наверненні їх до саморозвитку, самовиховання, самореалізації і самодіяльності. Зберегти своє здоров'я, згідно 3 дослідженнями, людина може тільки за допомогою діяльності (Бех, 2012, с. 34). Тому виникає необхідність включати майбутніх фахівців у спеціально організовану та різноманітну діяльність, де формуватиметься їхня потреба діяти заради здоров'язбережування. Для цього необхідно створити такі умови, щоб особистості змогли накопичити досвід знань щодо збереження та зміцнення здоров'я.

У роботі з майбутніми вчителями найбільш поширеними формами навчання $\epsilon$ лекції, на яких студенти ознайомлюються з основними категоріями й закономірностями дисциплін, їхніми методологічними основами, отримують проблемні матеріали, опрацьовують їх, висловлюють своє ставлення, формують власну позицію, яку потім відстоюють у дискусії. Дискусія забезпечує глибоке засвоєння теми, розвиває уміння працювати у команді, творчо взаємодіяти 3 іншими людьми. Наприклад, у навчальній дисципліні «Технології створення здоров’язбережувального середовища» в темі «Культура здоров'я. Новий сучасний напрямок у вихованні здоров'язбережувальних навиків молодого покоління» доцільним $є$ проведення групової дискусії на тему «Основні причини появи і закріплення шкідливих звичок у молоді».

Варіанти відповідей студентів:

Bidnoвids студента $K$ : соціальна узгодженість. Якщо та чи та модель поведінки прийнята в колективі одногрупників, до якої особистість належить або з якою вона себе ідентифікує, то майбутній фахівець уважає за необхідність слідувати їй, щоб показати свою приналежність до цієї групи; звідси - мода на шкідливі звички.

Biдnовідь студентки M: задоволення. Одна з головних причин, чому майбутні фахівці використовують шкідливі звички, - це супутні і приємні (спочатку) відчуття: від хорошого самопочуття та релаксації до містичної ейфорії. Далі виникає пряма залежність.

Відповідь студентки Л: інтерес - саме він змушує деяких студентів почати самим слідувати шкідливим звичкам та відхід від фізичного стресу. Більшості молоді вдається перебороти найбільші стресові ситуації життя, але деякі намагаються знайти прихисток у формі шкідливої залежності.

Biдnовідь студента B: невміння правильно використовувати вільний від навчання час; відчуження, незадоволення життям.

Під час самостійного опанування навчальними матеріалами, літературою майбутніх учителів нерідко виникає потреба порадитися з викладачем, з'ясувати складні питання, отримати рекомендації чи поради за методикою навчальної чи виховної роботи. Ця потреба задовольняється шляхом організації консультацій. Консультації проводяться за графіком, складеним кафедрою. Але в деяких випадках на прохання студентів та при необхідності консультації можуть проводитися й поза графіком. Наприклад, консультація з теми: «Куріння табаку - отрута для вашого організму» у вигляді порад і рекомендаиій для майбутніх учителів як відмовитися від куріння (Стойко, 2008, c. 23 ; Чепа, 2004, с. 35).

1. Уживайте слово «Ні!».

Залежно від обставин на пропозицію закурити можна чемно, щоб не образити, відповісти: «Дякую, не вживаю!», та якщо необхідно рішуче відмовитися, сказати коротко, але достатньо зважено і твердо: «Ні!».

2. Правильно розставляйте акценти.

Враховуючи реалії, доречність або недоречність ситуації, іноді краще не вживати фразу: «Я кидаю палити». Замість неї потрібно говорити: «Я не хочу палити». Різниця зовні не помітна, але, як свідчать дослідження, відіграє значну роль у психологічному настрої людини. 
1. Пізнайте себе.

Визначте, коли найбільше хочете палити: в авто, на заняттях, після їжі, перед сном? Завдання: встановити, коли Ви палите, чи дотримуєтеся якогось ритуалу. Замініть ритуальну сигарету (цигарку, люльку) іншим ритуалом. Наприклад, з'їжте яблуко чи підкиньте 20 разів у повітря коробку з сірниками. Корисно зробити 10 глибоких вдихів. Допоможуть також жувальна гумка, льодяники.

4. Воля та рішучість.

Хоча існує багато медикаментів, які допомагають позбутися нікотинової залежності, особливо довіряти їм не слід, тому що головне в цьому - воля та рішучість людини. Доки людина сама не захоче кинути палити, їй ніхто не допоможе.

5. Переконайте себе, що Ви не хочете палити, а також у тому,що рішення припинити це безглузде заняття по відношенню до здоров'я правильне. Для цього досить занотувати на листку паперу ту шкоду, яку вам завдало чи може завдати паління. Приміром, можна написати таке: «На сигарети я витрачаю стільки-то (сума грошей) на день. На рік ця сума становить стільки-то... Через тютюн я став більше хворіти. Мої діти (онуки, дружина, чоловік, одногрупники, друзі) бачать, що я палю, й теж можуть захотіти спробувати» тощо.

6. Пам’ятайте, що фізичний потяг до тютюну не триває безкінечно. Дослідження показують: він зникає протягом 48-72-х годин після останнього випадку паління. Надалі Вам доведеться боротися не 3 фізичною, а 3 психологічною залежністю.

7. Займайтеся здоров'язбережувальною активністю.

Результативні способи полегшити відвикання від тютюну - фізичні вправи. Тренування слід починати ще до того, як Ви вирішити назавжди кинути палити. Дослідженнями доведено: люди, які займаються фізичними вправами, значно легше і швидше відвикають від паління. Крім того, вправи допомагають зберегти вагу, оскільки багато колишніх курців після відмови від тютюну, як правило, починають гладшати.

8. Паління не привід для перерви.

Часто паління - лише привід для перерви. Замість того, щоб іти до смердючої курилки, просто пройдіться трохи затишною вулицею або парком, де є зелені насадження, свіже повітря.

9. Не випробуйте долю.

Ви потребуєте допомоги близьких і рідних. Попросіть членів родини та друзів не дозволяти Вам купувати тютюнові вироби, а частіше складати Вам компанію, коли Ви будете заміняти сигарету прогулянкою. Коли Ви вирішите відмовитися від паління, Вам доведеться подолати багато спокус. Тому краще не випробовувати долю і деякий час не ходити на вечірки, до барів тощо, тобто, не відвідувати, хоча б тимчасово, ті місця, де палять.

10. Зупиніться повністю та безповоротно.

Пам’ятайте про головну помилку: якщо Ви скоротили кількість випалених цигарок до однієї на день - Ви все одно продовжуєте палити. А це самообман. Прагніть зупинитися повністю і безповоротно.

11. Спілкуйтеся з тими, хто не палить.

Підтримуйте зв'язки переважно з тими, хто загалом не палить (або колись палив, але вчасно, свідомо та охоче позбавився від цієї звички).

12. Пригадайте всі недоліки паління.

У житті можливо все. Тож може статися так, що Ви раптом захочете палити. У такому разі згадайте про всі недоліки паління, уважно перегляньте їх знову і знову.

13. Ніколи не втрачайте надії. Вона, як відомо, вмирає останньою!

Бесіда - форма обгрунтування викладачем життєво важливої здоров'язбережувальної теми, формування питань, які спонукають особистість майбутнього вчителя до розмови. Як прийом пропонуємо бесіду за круглим столом (Вєтрова, 2012, с. 75). Бесіду проводять за круглим столом у невимушеній атмосфері, вона зорієнтована на здоров'язбережувальну тематику без настанови досягнути чіткого результату. Це особлива форма дискусійного навчання з обговоренням, яка полягає в сприянні розвитку здоров'язбережувальної компетенції в майбутніх учителів через вільний обмін досвідом і думками та вироблення толерантного ставлення до висловлювань і переконань інших. Наприклад, тема «Алкоголь. Пияцтво - це лютий ворог здоров’ю», роботу проводимо у чотири етапи:

1-ий етап: ненав'язливе змістовне входження в розмову, орієнтація на тему з боку викладача, ознайомлення 3 інформацією: «Алкоголізм - хвороба, що характеризується насамперед непоборним потягом до алкоголю, вживання якого призводить до серйозних психічних і фізичних розладів, що порушують міжособистісні та суспільні відносини. Якщо пияцтво стає непомірним, то межі між пияцтвом й алкоголізмом стираються, нерідко перше переростає в друге. Медична статистика встановила, що приблизно 1 з 16 побутових п'яниць стає хронічним алкоголіком. Чоловіку для цього потрібно 3-10, а жінці - 1-3 роки» (Кобзиста, 2011, с. 19).

2-ий етап: висловлювання думок (спонукання з боку викладача до вільного висловлювання думок без елементів критики та оцінок). «Алкоголізм, який розвинувся в одного члена суспільства, стосується не тільки хворого, а й не менше 7-10 осіб із його найближчого оточення, котрі мають з ним сімейні, родинні, побутові або професійні стосунки. Отже, кожний випадок зловживання алкоголем затримує, гальмує розвиток суспільства і завдає шкоди його членам. Не забуваймо, що неповноцінні діти стануть дорослими і самі матимуть дітей. А це - реальна, страшна загроза генофонду нації».

3-ій етап: ненав'язлива підтримка та координація вільної комунікації з боку викладача, залучення до розмови всіх учасників процесу.

Варіанти тем для дискусій з обговоренням (Богданова, 2004, с. 9-10):

1. Зловживання алкоголем впливає на зовнішній вигляд людини. Обличчя набрякає, очі втрачають блиск, під ними з'являються мішки. У п’яниць часто синіє ніс, кровоносні судини обличчя постійно розширені у зв'язку з втратою еластичності стінками судин і постійною кисневою недостатністю. На жаль, зловживання вином перестало бути привілеєм лише чоловіків. Жінка, що п'є у 30 років, зазвичай, виглядає старшою, алкоголічка до 40 років перетворюється на стару. 
2. Алкоголь шкідливий для мозку. Більш ніж 30 \% алкоголю затримується в нервових клітинах головного мозку. Внаслідок одного сильного сп'яніння гине до 20 тис. клітин головного мозку. Алкоголь викликає залежність: психологічну і фізіологічну.

3. Алкоголь шкідливо діє й на внутрішні органи. Попадаючи в шлунок, спиртні напої сприяють виділенню великої кількості шлункового соку. Але цей сік бідний на пепсин - фермент, що сприяє перетравленню їжі, багатий на слиз, який перешкоджає нормальному перетравленню їжі, що призводить до запалення слизової оболонки шлунка. Тому в осіб, які зловживають спиртними напоями, часто буває гастрит.

4. Чим молодший організм, тим більш руйнівна дія алкоголю. Відомі випадки отруєння підлітків незначними, 3 погляду дорослих, дозами алкоголю. Алкоголь, потрапляючи в організм дитини, швидко розноситься кров'ю та концентрується в мозку. Внаслідок підвищеної рефлекторної збудливості навіть невеликі дози спиртного спричиняють у дітей бурхливу реакцію, важкі симптоми отруєння, що становить небезпеку для дітей, організм яких чутливий до токсичних речовин. Особливо вразлива є нервова система. На фоні алкогольної інтоксикації в тих підлітків, які пристрастилися до спиртних напоїв, може розвинутися цукровий діабет, порушення статевої функції та інше.

4-ий етап: підбиття підсумків, відзначення найцікавіших думок, порад і рекомендацій для майбутніх учителів як відмовитися від алкоголю (7):

1. Спрага - це не привід...

Ніколи не пийте тоді, коли відчуваєте потребу напитися.

2. Швидко пити небезпечно.

Між першим і другим келихом пива (міцного вина тощо) зробіть півгодинну перерву, між другим і третім одногодинну, четвертого не пийте зовсім.

3. Будьте чесними перед собою.

Пам’ятайте, коли людина починає пити, у неї з'являється схильність не зізнаватися собі, скільки випито.

4. Пийте воду.

Концентровані напої не пийте зопалу, а також без доброго ковтка содової або звичайної води.

5. Ніколи не пийте на роботі.

6. Ніколи не пийте на голодний шлунок.

7. Не пийте регулярно, а також у певний час і з певної нагоди (небезпечно, якщо хтось п’є тільки для того, щоб міцніше спати).

8. Не пийте, якщо Ви втомлені або знервовані, краще прийміть теплу ванну, потім - холодний душ або ж зробіть інтенсивну прогулянку.

9. Ніколи не вживайте алкогольних напоїв як ліків від неприємного фізичного чи морального стану.

10. Ніколи не пийте вранці і, особливо, на похмілля.

У закладах вищої освіти основою підготовки фахівців вважають самостійну роботу студентів. Керівництво вищої школи цілком розділяє цю думку і багато часу приділяє організації цієї форми навчальної роботи. Самостійна робота сприяє формуванню високої культури розумової праці студентів, допомагає сформувати корисні навички та вміння, служить головним засобом перетворення знань у переконання. Фрагмент програми самостійного вивчення 3 навчальної дисципліни «Технології створення здоров'язбережувального середовища у вищих навчальних закладах» представлено в таблиці 1.

Таблиця 1.

Фрагмент програми самостійного вивчення з навчальної дисципліни «Технології створення здоров'язбережувального середовища у вищих навчальних закладах»

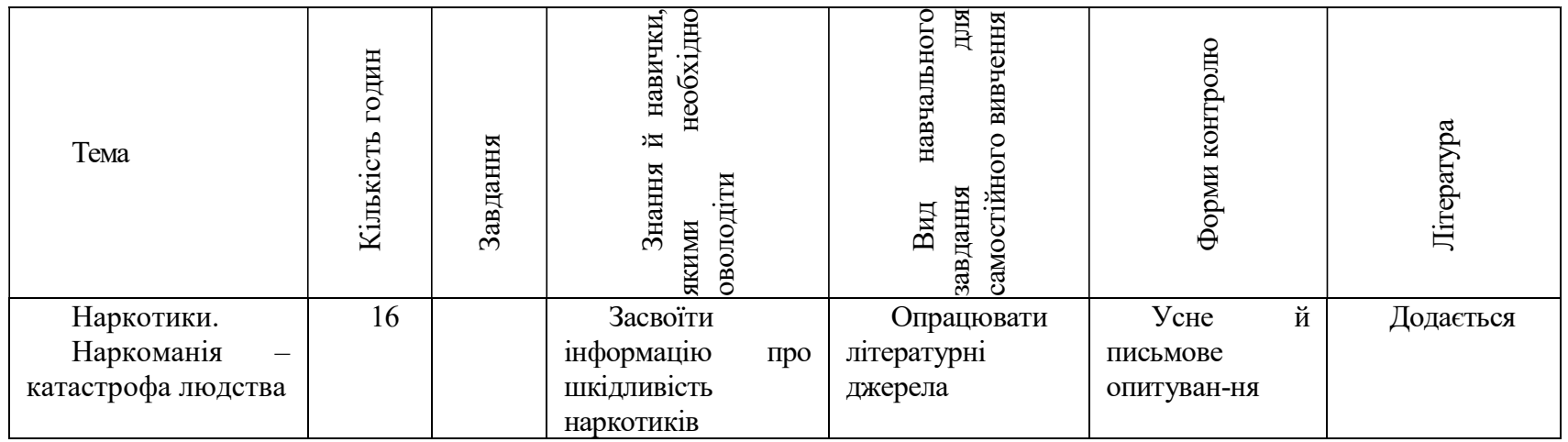

Варіанти завдань для самостійного опрацювання.

Користуючись рекомендованою літературою:

Завдання 1. Охарактеризувати психічні та фізичні прояви наркоманії.

Завдання 2. Визначити, які речовини відносять до наркотичних.

Завдання 3. Визначити та проаналізувати стадії, які проходить людина з наркотичною залежністю.

Завдання 4. Записати в зошит ознаки-поради, які можуть підказати, маєте Ви справу з наркоманом чи ні:

1. Недбале ставлення до своєї зовнішності.

2. Блідість, нездоровий зовнішній вигляд, причому явно виражена зміна кольору шкіри.

3. Почервонілі очі - скарги на біль в очах, свербіж, подразнення від світла.

4. З Значне розширення або звуження зіниць - залежить від уживання стимуляторів (у першому випадку) або седативних препаратів (у другому випадку). 
5. Пересохлий рот.

6. Проблеми з диханням та ускладнення з легенями.

7. Болі в животі та розлади травлення.

8. Висока стомлюваність, сонливість, апатія. Або ж, навпаки, - настирне безсоння, сильна дратівливість і агресивність.

9. Тремтіння в кінцівках.

10. Погана орієнтація в просторі - схильність зачіпати дверні ручки та одвірки, плутати напрям, навіть коли рухається знайомою дорогою тощо.

11. Раптовий вовчий апетит після довгого періоду байдужості до їжі.

Висновки. Отже, культура здоров'я особистості майбутнього вчителя - це частина загальної культури майбутнього фахівця, що охоплює педагогічні, психологічні, медичні, правові, соціальні аспекти. Це позитивний результат здоров'язбереження, що забезпечує єдність фізичного, психічного, духовного й соціального розвитку особистості.

Перспективи подальшої розробки проблеми полягають у подальшому вивченні питання формування культури здоров'я особистості майбутнього вчителя в здоров'язбережувальному середовищі закладу вищої освіти.

\section{Список використаних джерел}

Березин, С., Лисецкий, К. (2004). Классификация наркотиков и типы зависимости. Основы безопасности жизнедеятельности, 1, 22-28.

Бех, І. Д. (2012). Особистість у просторі духовного розвитку. Київ: Академвидав.

Богданова, Л. Є. (2004). Тверезість - норма життя. Хімія, 6, 8-11.

Ветрова, О. Д. (2012). Сучасні методи і форми роботи з обдарованими дітьми. Наукові записки Ніжсиського державного університету імені М. Гоголя, 3, 73-75.

Кобзиста, М. В. (2011). Шкідливий вплив тютюну, алкоголю, наркотичних речовин на репродуктивне здоров'я. Основи здоров'я, 11, 14-19.

Колбанов, В. В., Берсенева, Т. А. (1995). Валеологическая служба в образовательных учреждениях. Проблемы валеологии в образовании. Липецк.

Корисний світ. Корисні поради жінкам. Взято з: http://ywoman.ru/page/korist-vodi-dlja-organizmu-chomu-treba-piti-vodu.

Минияров, В. И. (1992). Физическая культура в повышении соииальной активности студента. Физическая культура в процессе обучения и профессиональной подготовки учителя. Москва: МГПИ им. В. И. Ленина.

Митяева, А. М. (2008). Здоровьесберегающие педагогические технологии. Москва: Академия.

Стойко, О. О. (2008). Нарешті я не палю, або легкий спосіб кинути палити. Психологічна газета, 12, 3-24.

Чепа, М. (2004). Психологічні особливості формування тютюнозалежності та шляхи їі подолання. Безпека життєдіяльності, 5, 21-26.

\section{References}

Berezin, S., Lisetskiy, K. (2004). Klassifikatsiya narkotikov i tipy zavisimosti [Drug classification and types of addiction]. Osnovy bezopasnosti zhiznedeyatelnosti [Life Safety Basics]. 1. 22-28 [in Russian].

Bekh, I. D. (2012). Osobystist u prostori dukhovnoho rozvytku [Personality in the space of spiritual development]. Kyiv: Akademvydav [in Ukrainian].

Bohdanova, L. Ye. (2004). Tverezist - norma zhyttia [Temperance is the norm of life]. Khimiia [Chemistry], 6, 8-11 [in Ukrainian].

Chepa, M. (2004). Psykholohichni osoblyvosti formuvannia tiutiunozalezhnosti ta shliakhy yii podolannia [Psychological features of the formation of tobacco dependence and ways to overcome it]. Bezpeka zhyttiediialnosti [Life Safety], 5, 21-26 [in Ukrainian].

Kobzysta, M. V. (2011). Shkidlyvyi vplyv tiutiunu, alkoholiu, narkotychnykh rechovyn na reproduktyvne zdorovia [Adverse effects of tobacco, alcohol, drugs on reproductive health]. Osnovy zdorovia [Health Basics], 11, 14-19 [in Ukrainian].

Kolbanov, V. V., Berseneva, T. A. (1995). Valeologicheskaja sluzhba v obrazovatel'nyh uchrezhdenijah. Problemy valeologii v obrazovanii [Valeological service in educational institutions. Problems of valeology in education]. Lipeck [in Russian].

Korysnyi svit. Korysni porady zhinkam [A useful world. Useful tips for women]. Retrieded from http://ywoman.ru/page/korist-vodidlja-organizmu-chomu-treba-piti-vodu [in Ukrainian].

Minijarov, V. I. (1992). Fizicheskaja kul'tura v povyshenii social'noj aktivnosti studenta. Fizicheskaja kul'tura v processe obuchenija i professional'noj podgotovki uchitelja [Physical education in increasing student social activity. Physical education in the process of teacher education and training]. Moskva: MGPI im. V. I. Lenina [in Russian]. 
Mitjaeva, A. M. (2008). Zdorov'esberegajushhie pedagogicheskie tehnologii [Health-saving pedagogical technologies]. Moskva: Akademija [in Russian].

Stoiko, O. O. (2008). Nareshti ya ne paliu, abo lehkyi sposib kynuty palyty [Finally I don't smoke, or an easy way to quit smoking]. Psykholohichna hazeta [Psychological newspaper], 12, 3-24 [in Ukrainian].

Vetrova, O. D. (2012). Suchasni metody i formy roboty z obdarovanymy ditmy [Modern methods and forms of work with gifted children]. Naukovi zapysky Nizhynskoho derzhavnoho universytetu imeni M. Hoholia [Scientific notes of Nizhyn M. Gogol State University], 3, 73-75 [in Ukrainian].

\title{
MOMOT O., KIRILENKO A.
}

Poltava V. G. Korolenko national pedagogical University, Ukraine

\section{THE FORMATION OF THE CULTURE OF HEALTH OF THE PERSONALITY OF THE FUTURE TEACHER IN HEALTHY ENVIRONMENT OF HIGH SCHOOL}

The article reveals the ideas of forming a culture of health, prevention of bad habits of students (tobacco smoking, alcoholism, drug addiction) by means of methodical tips and recommendations in a healthy environment of high school, which educate the quality of the person reflecting the nature of the interested person lifestyle and environment.

It is possible to create a culture of health for future teachers when they are focused on health care through the pedagogical education system itself. The pedagogical effect should not only consist in the accumulation of new knowledge, skills, development of a positive motivational attitude to health, but also be expressed in self-development, self-education, self-realization and self-activity. Therefore, there is a need to include future professionals in specially organized and diverse activities where their need to act for the sake of health is formed. You need to create the conditions for individuals to gain experience in maintaining and promoting health.

The future teacher teacher's health culture is part of a general future teacher's culture that encompasses pedagogical, psychological, medical, legal, and social aspects. It is a positive health result that ensures the unity of the physical, mental, spiritual and social development of the individual.

Keywords: the formation of the culture of health; healthy environment; personality of the future teacher; health, high school

Стаття надійшла до редакції 21.09.2019 р.

УдК 378.011.3-051:73/76

DOI: https://doi.org/10.33989/2075-146x.2019.24.194860

\section{ІРИНА МУЖИКОВА}

ORCID ID 0000-0003-0473-3271

Полтавський національний педагогічний університет імені В.Г. Короленка

\section{ФОРМУВАННЯ ФАХОВИХ КОМПЕТЕНТНОСТЕЙ МАЙБУТНІХ УЧИТЕЛІВ ОБРАЗОТВОРЧОГО МИСТЕЦТВА У ПРОЦЕСІ МЕТОДИЧНОЇ ПІДГОТОВКИ}

\begin{abstract}
У статті розглянуто проблему формування фахових компетентностей майбутніх учителів образотворчого мистецтва у процесі методичної підготовки. Зазначено, що проєктування зазначених компетентностей грунтується на традиціях навчання образотворчого мистецтва, здобутках мистецької педагогіки та досягненнях української освітньої науки і практики. Визначено, що формування фахових компетентностей здійснюється у три етапи на кожному з яких майбутні учителі набувають знань, розумінь, когнітивних та практичних навичок навчання образотворчого мистецтва.
\end{abstract}

Ключові слова: методична підготовка; фахові компетентності; учитель образотворчого мистецтва; образотворча грамота; методика навчання образотворчого мистецтва

Постановка проблеми. Реформування української освіти зумовлює необхідність осучаснення процесу підготовки майбутніх учителів образотворчого мистецтва у педагогічних університетах. Зокрема актуальною $\epsilon$ потреба в адаптуванні традиційно усталеної системи підготовки майбутніх фахівців 3 навчання образотворчого мистецтва у закладах загальної середньої освіти до нормативних та організаційних змін у сфері вищої освіти, до перспектив розвитку професії та очікувань суспільства. Аналіз практики підготовки майбутніх учителів 